\title{
The Religious Multicultural Values in the Religiosity Experiences Found in Husni Djamaluddin's Poetries
}

\author{
Muliadi \\ Universitas Muslim Indonesia, Makassar \\ Email:mulssam@yahoo.co.id
}

\begin{abstract}
Poetry is a literal work representing action and thought of the poet after interacting with both inner worlds, his/her thought, and outer worlds, phenomena. This research attempted to deliver an idea about a model of multicultural study by utilising the poetry texts as the data source. The research scope was limited to religious multicultural values; (1) personal freedom, (2) sacrifice, and (3) uncontrolled sexual desire (adultery). Multicultural is one way to understand the diversity. There is a connection between the religiosity and divinity. Being religious is also about how human communicates with their creator, God. This research was a qualitative where the data were words, lines, and paragraphs in the chosen poetries. The data were subjected to analysis of Ricoeur hermeneutic approach. Husni Djamaluddin asserted that that freedom is always bonded with obligation. Sacrifice refers to the essence of kindness and greatness of all creatures. The awareness of each individual as the organic part of the society that must obey the customary law, religion law, and national law is the main key to prevent the uncontrolled lust release in the community.
\end{abstract}

Keywords: Value, Multicultural, Religious

\section{INTRODUCTION}

The word valuein English is synonymous with valere in Latin, and valoir in Old French, which means preciousness or goodness (Mulyana, 2004:7). If it is understood in a specific context, value is something phenomenal and very unique to the human life. It is phenomenal because not all people agree to have similar way to define value. Each person may not give similar value to the similar observed object. For example, two women are offered golden bracelet. They may value this jewellery differently. One says that it is beautiful and she insists on having it, while the other denies it due to its model, and refuses to possess it.

Iskandar (1998:864) noted that values represent a degree, quality, level, thought, religion, and community. Value is highly meaningful, worthy, important, and needed in the human life. Gazalba (1998;33) said that values were considerably precious by a person a group of people. Ali ibn Abi Thalin, The Prophet Mohammad's companion (in al-Qarni, 2008:178) said that the human value remained in the good deeds. In other words, the knowledge that human possesses along with politeness, piety, generosity, and morality are the actual values describing a person rather than the human face, style, and social status. The God has declared in the Qur'an (in Chapter of Al-Baqarah: 221) that "indeed, slave who is a believer is better than she who believes in polytheist even though 
she is attractive to you. In the Islamic context, the poet religion, believing in God is a very good deed.

The word "multicultural" is derived from two words, multi and culture. Suffix -ismwas added to this word resulting in multiculturalism. Mahfud (2006:75) asserted that the meaning of multiculturalism is to respect the dignity of human kind who lives in the community with the different unique culture they possess. Every individual must be recognized as the member of their community, and responsible to live hood of the community. Community denial on the need of being recognised (the politics of recognition) can be the root of social disorder. Maryaeni (2013; 132) observed that multiculturalism contained noble values, that must be preserved and considered for daily practice. Liliweri (2003) asserted that multiculturalism was made of many cultures professed by a community. Thus, community has to have good understanding about them. Also Suparlan (2009) noted that multiculturalism was an ideology stressing on recognition and appreciation to the equal standing of different cultures. It is supported by Ganap (2012:158) who said that the essence of multiculturalism is equality. Based on these concepts above, multiculturalism can then be understood as the result of an agreement, acceptance, and equality, from which the existence of different cultures professed by certain ethnic/tribe will be respected and considered of having noble values.

Religious is related to a belief in a religion. If it is linked to the word 'value' then it becomes religious value, it talks about how human has relationship with God and His creatures. Such value is often found in old literal works or ancient literatures. In many primitive communities, literal works were made for religious ceremonies. Throughout the history of humanity, literatures were liked with the dimension of religious values many times.

Religious value is a very complex issue because it concerns not only with God but also with the relationship among humans and the relationship between human and nature. In the Islamic perspective, the religious value concept is divided into three categories, (a) faith (iman), (b) Islam, and (c) virtue (ikhsan).

In this research, the word "religiosity "is not linked to one particular religion, Islam, because the meaning of being religious is general or even neutral. Indeed, religious is derived from the word of religion which means "bonding or submission, compliance and obedience". The submission and obedience are related to happiness. The happiness comes when a person seemingly is entering new world which is full of nobility (Drijarkarna $\mathrm{N}$ and James W. in Atmosuwito, 2010:123). Thus, the religious concept is general concept which is in line with multicultural concept.

Based on the overview above, the religious multicultural values must be general or universal. The religious multicultural value discussed in this paper as mentioned in the tittle means the religiosity experience. The term "religiosity experience" relates with social issues which are relevant to socio-community issues. It becomes the representation of the belief values on religion and religious attitudes control the harmony between person and other people, an individual and nature or environment. The religiosity experience encompasses three aspects; (1) personal freedom, (2) sacrifice, and (3) uncontrolled sexual desire. This paper is part of the author's doctoral thesis entitled Multicultural Values of Husni Djamaluddin Poetries' Texts Using Hermeneutic Study.

Three aspects above were examined in Husni Djamaluddin's poetries. These poetries then become the source of data. Husni Djamaluddin (HD) was a highly famous poet from South Sulawesi in Indonesia's literatures. Poets from South Sulawesi showed great appreciation to his works because of the deep and the sharp meaning of his works. Taufiq Ismail (in Yunus et al, 2004: 247) stated that the poets who were able to write a deep-meaning poetry were only those who have struggled intensively within physical and mental experiences. Ismail wrote a reflection by saying, "Thanks 
Husni, when can I follow your path to be with God alone?" Also, A. Moein MG (in Yunus et al, 2004;1) awarded Husni Djamaluddin a nickname "the Commander of Poetry" for his competence and diligence in composing the words into poetry, and also for his loyalty in writing poetries until his death. During his hospitalization at RSPAD Gatot Subroto, Jakarta, he wrote poetry. The tittle of the Poetry that he made just before his death was Death, before its Coming, and What People Say about conglomerate HPH. The following is the last poetry he made.

\section{APA KATA RAKYAT TENTANG HPH KONGLOMERAT}

Seluruh kawasan hutan ini

Kita yang punya

Kecuali

Pepohonanya

17 Agustus 2004

The English translation

\section{WHAT PEOPLE SAY ABOUT CONGLOMERATE HPH}

\author{
All of these forests \\ Belong to us \\ Except \\ The trees
}

\section{August 2004}

Poetry is a literal work reflecting the action and the way of thinking of the poet after struggling with his/her thought or phenomena. This struggle can produce variety of values including those relating to philosophy, aesthetic, ethic and belief. It is consistent with Amir $(1986$; 183) who said that good literal works would meet the demand for unity and integration of various values, including religious, philosophical, esthetical and ethical values. Of which, religious value is related to religiosity experience.

There had been two studies relating to Husni Djamaluddin's works by Adri (2007) and Musayaadah (2010). The first one studied the semiotic analysis of the HD's poetries. The later researched the aesthetic values of HD's poetries. There has not studied yet regarding to religious multicultural values based on the religiosity experience in HD's works.

The previous studies did not study HD's views on diversity of South Sulawesi people. Furthermore, they studied one of HD's poetry entitled "Indonesia, Masihkah Engkau Tanah Airku?" it was cited from a set poetries which consisted of four poetries; Bulan Luka Parah, Berenang-Renang Ketepian, Namaku Toraja, dan Indonesia, Masikah Engkau Tanah Airku.

The current study aims at revealing the three multicultural concepts in HD's works. They are the concepts of freedom, sacrifice, and uncontrolled sexual desire.

\section{APPROACH}

Research data were obtained from words, lines, and paragraphs from the texts of Husni Djamaluddin poetries. They were adjusted with the paper focus. The focus was given upon texts in Husni Djamaluddin's poetries compilation that entitled Indonesia, Masikah Engkau Tanah Airku? These texs were read few times. The result of the reading was then followed with identification, classification, analysis and sense-making.

Referring to the used data then the research employed qualitative method. The approach used to reveal the meaning or value in Husni Djamaluddin's poetries was hermeneutic, Ricoeur hermeneutic. As noted by Ricoeur, hermeneutic was a theory about rules of interpreting texts, or defining signs or symbols considered as text (Suratno, $2005 ; 105)$. Thus, hermeneutic will reveal the meaning behind symbols.

Ricoeur (2006) stated that a text is autonomous or independent from the purpose of the author (because reader can use their own interpretation). Ricoeur hermeneutic involves estimations. One estimation predicts others. Texts contain inherent plurality of meanings which can be understood with various ways. Indeed, interpretation is an open process but it cannot be used arbitrarily or be changed easily. In deep interpretation, the interpreter 
enters the textual world, follows the meaning flow toward the other meaning (reference) and from internal structure to the projection world (Rafiek, 2010:6).

Ricoeur hermeneutic involves several steps. (1) First is the symbolical step or understanding symbols. (2) Second is giving meaning according to the symbols and finding out the deep meaning. (3) Final step is philosophical analysis, which involves thinking of something using symbols as the early departure point. All these steps are closely relating to linguistic comprehension, including semantics, reflexive, and existential or ontology (Sumaryono, 1999:111). These three steps must be helpful in revealing religious multicultural value of religiosity experience in Husni Djamaluddin poetries. Religiosity experience includes some aspects such as personal freedom, sacrifice and uncontrolled sexual desire. These aspects are explained as follows.

\section{PERSONAL FREEDOM}

HD's poetry in the following provides data about multicultural value in personal freedom aspect.

\section{Kemerdekaan Yang Aku Rindukan}

kemerdekaanyang aku rindukan

bukanlah kemerdekaan untuk menutup pintu -pintu

rumah kehidupan orang lain

menyetop perjalanan pikiran orang lain

membungkam mulut orang lain

yang suara

dan pendapatnya berbeda.

menyindir-nyindir setajam pisau silet

mempermalukan orang lain

adalah kemerdekaan untuk menjaga

kemuliaan manusia

agar dimana saja

hidup layak, sejahtra

dan terhormat

(Djamaluddin, 2004:210)
The English translation

\section{The Freedom That I Yearn For}

The freedom that I yearn for

It is not the freedom of shutting

the doors of others' lives,

stopping the thinking journey of others,

shutting the voice of others

whose voice

and opinion are different,

Teasing as sharp as razor blade,

humiliating others.

It is the freedom to keep

the greatness of human

so wherever they are

They live in prosperity, wealthy life

and with dignity.

To understand and find out multicultural values in the poetry "Kemerdekaan yang aku rindukan". It can be done by finding out its information unit. It is the words in the sentence intentionally selected with instruments of enjambments and interpolation. Using these two instruments the information units can be described as following:

\section{The Freedom That I Yearn For}

/The freedom/ that I yearn for/

It is not the freedom of shutting

the doors of others' lives/

stopping the thinking journey of others/

shutting the voice of others

whose voice/

and opinion are different//

Teasing as sharp as razor bladel

humiliating others//

It is the freedom to keep

the greatness of human/

so wherever they are

They live in prosperity, wealthy life

and with dignity//

After marking poetry with enjambments and interpolation, there were 
three information units found with the sign (//) as negation sign or functioning as the end of sentence. It is similar to the sign (.) in the written language. To find out the semantic meaning of these 3 information units, the words or phrases in between the signs (/) the beginning of the sentence and (//)final sign of the sentence would be categorised into subjects and predicate as following.

\begin{tabular}{|l|l|}
\hline Subject & \multicolumn{1}{|c|}{ Predicate } \\
\hline Freedom & $\begin{array}{l}\text { that I yearn for, Is not freedom } \\
\text { of shutting the doors of others } \\
\text { lives, stopping the thinking journey } \\
\text { of others, stopping the voice of } \\
\text { others whose voice and opinion are } \\
\text { different. }\end{array}$ \\
\cline { 2 - 2 } & $\begin{array}{l}\text { (it is not the freedom of) teasing as } \\
\text { sharp as razor blade, humiliating } \\
\text { others. }\end{array}$ \\
\cline { 2 - 2 } & $\begin{array}{l}\text { It is (the freedom) to keep submility } \\
\text { of human wherever they are, they } \\
\text { live in prosperity, wealthy and with } \\
\text { dignity. }\end{array}$ \\
\hline $\begin{array}{l}\text { Note: } \\
\text { Words in parenthesis are shown (by interpolation) } \\
\text { to imply information inscribed in the sentence }\end{array}$ \\
\hline
\end{tabular}

Based on the abstraction above, the word "kemerdekaan" meaning freedom is put into subject category and referring to a semantic. This word is derived from the word "merdeka" in English equal to "free" and then it is added with prefix "ke" and suffix "an" which becomes "kemerdekaan" or freedom in English word. The word "merdeka" has denotative semantic which is synonymous with the word "bebas" meaning free soul or free society. Therefore, the semantic of the word "kemerdekaan" or freedom is related to the need for freedom of soul and society. Freedom as the need for the soul exists in the individual dimension, whereas freedom as the need for the society is relating to the collective (group) dimension.

Denotative semantic of the word "kemerdekaan" can be further explained that the need for freedom begins from individual dimension, but the daily practice of this need overlaps with collective dimension. Freedom in the individual dimension is the consequence of soul potential bestowed by God given a fact that every individual has right to have wills and plans to their lives and they also have rights to select proper actions to pursue both.

This reflection formulation offers useful guidance to find out the existence of freedom under justice perspective, either at individual or collective dimensions. In the poetry "Kemerdekaan yang Aku Rindukan" indicates the freedom existence as formulation of ideallity and chosen action.

Freedom comprehended as an ideality would be a philosophical formulation or verbal construct on individual. In the poetry, the ideal construct can be found in the semantic of words "Bukanlah" or is not and the word "adalah" or is(namely). Both words remain in the predicate because both give ideality demarcation. The word "bukan" (is not) is put into the category of disfavored ideality demarcation while the word "adalah" or is(namely) remains in the category of favored ideality demarcation. Regarding to the word freedom itself, Rasuanto (2005; 46) said that freedom cannot be negotiated or compromised with the bigger social and economical interests. Freedom is the right of every individual. It is to say that freedom is the highest value for humanity.

The freedom existence as an elective choice of action is shown by some verbs in predicate category, such as: (1) shutting the doors of others, (2) stopping the mind of others, (3) stopping the voice of others whose voice and opinion are different, (4) teasing as sharp as razor blade, (5) humiliating others, and (6) keeping the greatness of human. Statement 1 to 4 follow the word "bukan" or is not and they are set into category of disavoredly chosen actions. Statement 5 follows the word "adalah" or is(namely) and enters the category of favoredly chosen action.

Semantic, reflective and existential perspectives for the word "kemerdekaan" are very useful modes to understand the multicultural value of justice and personal 
freedom. In this case, freedom remaining in the individual ideality - psychological aspect - must be manifested into the chosen actions - sociological aspect- which should not collide with ideality of other individuals. The ideality with the chosen action could be described as freedom attached with justice. It is said so because individual has two kinds of interests, self-interest and social-interest. Under sociological perspective, socialinterest precedes self-interest. Having said that the first thing binds an individual is an obligation and rights come after.

Husni Djamaluddin attempted to tell that freedom always came with an obligation. Thus, the application of the multicultural value of personal freedom in community should be in the state of understanding of the obligation and rights are two equal concept (Cardinas, 1975; 131).

\section{SACRIFICE}

The following Husni Djamaluddin poetry provides data about multicultural value in a sacrifice aspect, giving charity.

\section{Saat-saat Terakhir Muhammad Rasulullah}

ada kulihat

matamu berisyarat

adakah gerangan

yang ingin kau pesankan

dalam jam-jam penghabisan

wahai Nabi pilihan

maka kuhampirkan telingaku yang kanan

di mulutmu yang suci

maka kudengar ucapan pelan: di bawah tikar

masih tersisa sembilan dinar

tolong sedekahkan

sesegera mungkin

kepada fakir miskin

(Djamaluddin, 2004: 67)
The English translation

\section{The Last Moment of Muhammad Rasulullah}

I see

your eyes signalling something

is there something

you want to share

in your last minutes of life

ohh.. The chosen prophet

I take my right ear close to you

Next to your holy lips

then I hear whispering voice: under the mat

nine coins of dinar (currency in his era) , are left

please donate

as soon as possible

to the poor

Multicultural value of sacrifice is found in the poetry by discerning information unit. Information unit is words in the sentence that are selected intentionally with instrument of interpolation. As a result, the data are arranged as following.

\section{The Last Moment of Muhammad Rasulullah}

I see/

your eyes signalling something/

is there something/

you want to share/

in your last minutes of life/

ohh.. The chosen prophet//

I take my right ear close to you/

Next to your holy lips//

then I hear whispering voice:

under the mat/

nine coins of dinar (currency in his era) ,are left/

please donate/

as soon as possible/

to the poor// 
After marking the poetry with enjambments and interpolation, it indicates that four information units are given, the sign $(/ /)$ as the negating sign or functioned as the end of sentence. It refers similarly to full stop (.) in the written language. To find out the four semantic meanings of these information units, the words or phrases in between the signs (/), the beginning of the sentence, and (//)final sign of the sentence, would be categorised into subjects and predicate as following.

\begin{tabular}{|c|l|}
\hline Subject & \multicolumn{1}{|c|}{ Predicate } \\
\hline \multirow{2}{*}{ I } & $\begin{array}{l}\text { (to) See your eyes signalling } \\
\text { something, is there something } \\
\text { you want to share in your last } \\
\text { minutes of life ohh.. The chosen } \\
\text { prophet }\end{array}$ \\
\cline { 2 - 2 } & $\begin{array}{l}\text { take my right ear close to you. } \\
\text { Next to your holy lips }\end{array}$ \\
\cline { 2 - 2 } & $\begin{array}{l}\text { hear whispering voice: under the } \\
\text { mat, nine coins of dinar (currency } \\
\text { in his era) are left }\end{array}$ \\
\hline $\begin{array}{l}\text { (You) } \\
\text { (ask for favor) please donate } \\
\text { (those nine dinars), as soon as } \\
\text { possible, to the poor. }\end{array}$ \\
\hline $\begin{array}{l}\text { Note: } \\
\text { Wordsin parenthesis is shown(interpolation) } \\
\text { to imply information inscribed in the } \\
\text { sentence }\end{array}$ \\
\hline
\end{tabular}

Both words "I" and "you" are put into subject category. The word "I" has double semantic, to be precise it is the pronoun of first person (singular) representing Husni Djamaluddin as the poet. The word "you" also refers to double semantic, it is the pronoun of singular of second person representing the chosen Prophet. This poetry shows the religion of Husni Djamaluddin as Moslem. Therefore, the word you in the statement "your eyes signalling something" is addressed to the Prophet, Muhammad.

It is then known that semantic concerning with words $I$ and you is inscribed into four information units. First information unit shows the spiritual experience of Husni Djamaluddin in seeing the sign transmitted on the Prophet's eyes at his agony. Second information unit is the semantic of Husni Djamaluddin's spiritual experience in taking his ear to the Prophet's holy lips. Third information unit concerns with semantic of Husni Djamaluddin's spiritual experience in listening to the message that there are nine coins left under the mat. Fourth information unit is a semantic of Husni Djamaluddin's spiritual experience showing that there is a message from the Prophet to give nine coins of dinar to the poor.

These four information units provide reflection that the essence of the prophet Muhammad's teaching of virtues is giving charity by the fortune people to the misfortune people. More or less misfortune and fortune persons are only complementary each other like the North and South Poles.

Result of this reflection indicates that the existence of people in the world is to give, not to ask. To be able to give on behalf of God, human must act giving goodness for themselves and other creatures. To give means to get. The result of semantic, reflexive and existential aspects analysis shows that Husni Djamaluddin attempts to persuade others or readers to understand that being a good person or good creature is not adequate by only worshipping God or thinking about self-interest, but also caring or sacrificing to other creatures. If you dream of being a good creature then you have to sacrifice. Oentoro (2011:111) stated that to be a good person, a sacrifice should be made.

Based on the semantic, reflexive, and existential aspects of the findings, it can be said that the multicultural value in the sacrifice dimension is applicable for all humans. In this context, sacrifice would be the essence of virtues and greatness. In other words, if you want to be kind and great person, then make sacrifice or give charity. It must be consistent with the proverb "to give is better than to ask".

\section{UNCONTROLLED SEXUAL DESIRE}

Husni Djamaluddin's poetry in the following contains multicultural value in the aspect of uncontrolled sexual desire. 
Kisah Seekor Kucing dan Seorang Nyonya

seekor kucing

jantan belang kuning

indekos sejak lama

di rumah seorang nyonya

yang suaminya belajar di Amerika

dan terkenal

aktif sekali dalam kegiatan sosial

demikianlah jam kota

berdetak-detik biasa-biasa saja

sampai pada suatu ketika

malam menyebarkan alergi

dari sepi

dan tubuh kucing itu jadi tegang dan membengkak

makin tegang makin membengkak dan membengkak

terus kucing itu

jadi seekor harimau

malam itu

seekor harimau

menerkam dengan garang

seorang nyonya di atas ranjang

(Djamaluddin, 2004:39)

The English translation

\section{The Story of A Cat and A Lady}

A male cat

with yellow stripes

Renting a room for long time

At a lady's house

whose husband was studying in America and famous for

her very active in social activities.

The city clock was ticking

ticking normally

until one day

when the night spread allergy

of loneliness

and the body of the cat got strained and swelled

straining more, swelling more then

became a tiger

at that night

a tiger

fiercely caught

the lady on her bed

Multicultural value in the poetry above is gained by observing the information units. Information units refer to words in the sentence intentionally selected with instrument of enjambments and interpolation. In this poetry, data of information units are arranged as following.

\section{The Story of A Cat and A Lady}

/A male cat/

with yellow stripes//

/ranting a room for long time/

At a lady's house/

whose husband studying in America/

her very active in social activities//

city clock is ticking/

ticking normally/

until one day/

when night spreads allergy/

of loneliness//

and the body of the cat gets strained and swelled /

straining more, swelling more //

then/

(men-, prefix added to change noun into verb) becomes a tiger//

at that night /

a tiger /

fiercely catches on /

the lady on her bed //

When this poetry is subjected to enjambments and interpolation, there are six information units obtained, with the sign (//) as negation sign or signalling the end of the sentence. It has the same function of full stop (.) in the written language. The semantic of these six information units is comprehended by observing words or phrases between early 
sign (/) and final sign (//). All these words and phrases are set into subject and predicate categories.

\begin{tabular}{|l|l|}
\hline Subject & Predicate \\
\hline \multirow{4}{*}{$\begin{array}{l}\text { A male } \\
\text { cat }\end{array}$} & $\begin{array}{l}\text { Ranting a room for long time, at a } \\
\text { lady's house, whose husband was } \\
\text { studying in America, and famous } \\
\text { for her very active in social } \\
\text { events. }\end{array}$ \\
\hline $\begin{array}{l}\text { The city } \\
\text { clock }\end{array}$ & $\begin{array}{l}\text { was ticking, ticking normally, } \\
\text { until one day, when the night } \\
\text { spread allergy, of loneliness }\end{array}$ \\
\hline $\begin{array}{l}\text { The } \\
\text { body of } \\
\text { the cat }\end{array}$ & $\begin{array}{l}\text { got strained and swelled, straining } \\
\text { more, swelling more }\end{array}$ \\
\cline { 2 - 2 } then, became a tiger \\
\hline A tiger & $\begin{array}{l}\text { at that night, fiercely caught on } \\
\text { the lady on her bed. }\end{array}$ \\
\hline $\begin{array}{l}\text { Note: } \\
\text { Words in parenthesis is shown (interpolation) } \\
\text { to imply information inscribed in the } \\
\text { sentence. }\end{array}$ \\
\hline
\end{tabular}

The words "a male cat", "city clock", and "a tiger" are put into subject category referring to the semantic of certain material things. Each word has double semantic, denotative and connotative. The denotative semantic of cat and tiger is relating to an animal with certain shape and characteristics. The word city clock is a thing made with a certain shape and characteristics, and installed on city spot. On the other hand, connotative semantic of cat in the context of this poetry is also given for a man who was studying and he was rent in the lady's house as the host whose husband was on the leave for a quite long time. Next connotative semantic of tiger is the other name for a man who was renting a room in the lady's house but he was also sexually attracted to the lady whose husband was away. Finally, connotative semantic of city clock is a symbol of social condition or social dynamic of urban community.

Referring to the semantic words in the subject category, it can be inscribed six information units from the poetry. First is a semantic about the identity of a man who was renting a room in the house of a lady left by her husband. This man is given a symbol "yellow stripes", and it is possibly described as handsome and playboy. Second is about the status of the man who was staying with the lady. Third is a semantic of social condition and social dynamic of a free city life. Fourth is a description of sexual desire of the man to the lonely woman. The fifth is the semantic of the renter's sexual desire comparison. This sexual desired is compared to a tiger which was ready to catch on a prey. Sixth information unit provides a semantic of releasing sexual desire of the man to the lonely lady whose husband was studying in America.

The reflection of all these semantics is that the release of sexual desire of man and woman out of marriage is possible when there is the chance and it is supported by is social dynamic condition. In the biological perspective, it is reasonable to happen because men are sexual desire for woman because it is the innate potential after entering the puberty period. However, in sociological perspective, the release of sexual desire between man and woman out of marriage is considered as violation of ethics or social norms; customary law, religion law, and national law. The illegal sexual intercourse between man and woman is called adultery (uncontrolled sexual lust). M. Quraish Shihab admitted that adultery is a copulation of two different genitals without marriage. Also, Ibnu Rusydi stated similarly saying that adultery is a copulation without legal marriage. (in https://studipemikiranquranhadist. wordpress. com/2013/12/06/71/;accessed in13 March 2017).

From both semantic and reflexive findings, it can be said that uncontrolled lust is a conditional factor due to higher frequency of meeting or staying together, as described in the poetry. In Islamic perspective, as warned by the Prophet Muhammad, with his statement, "do not a man meet (khalwat) with a lonely woman in non-rightful occasion because the third was the devil, except the woman is hismuhrim, a person cannot be married due 
to family relation or guardians" (narrated by Ahmad).

Referring to the reflexive constructs, it can be said that the existence of adultery is the action of releasing sexual desire between man and woman beyond marriage or only for having fun, and it surely violates customary law, religion law, and national law. In other words, adultery cannot be judged from biological perspective only, but also it must be understood from sociological perspective.

Based on the semantic, reflexive, and existential findings, it can be concluded that multicultural value that is formulated into customary law, religion law, and national law, must bind all organic elements of society. The awareness of individual as the organic member of community to the existence of customary law, religion law, and national law. It is the main key to prevent adultery in the community. In this context, the meaning of multicultural value is the acknowledgement of the human dignity of human who lives in the community where each of individuals possesses unique personal culture (Mahfud, 2006; 75).

\section{CONCLUSION}

In the personal freedom discussion, Husni Djamaluddin understood that freedom is always related to an obligation. The application of multicultural of personal freedom is always equal to the rights of receiving opportunity, such as education.

Sacrifice is the essence of virtue and sublimity to all creatures. In the other words, being kind and sublime person would require making sacrifice or giving charity. It is consistent with a proverb "to give is better than to ask".

The individual awareness as the organic member of community that formulates the existence of customary law, religion law, and national law, is the main key to alleviate adultery in the community. In this context, multicultural value contains a recognition to the human dignity who lives in the community with their different unique cultures.

\section{REFERENCES}

Al-Qarni, A. (2008). La Tahzan (Jangan Bersedih). Terjemahan Samson Rahman. Jakarta: Qisthi Press.

Amaluddin (2009). Bentuk, Fungsi, Nilai, dan Strategi Pemertahanan Tradisi Lisan Nyanyian Rakyat Bugis. Disertasi tidak diterbitkan. Malang: PPs UM Malang.

Amir, H. (1986). Nilai-Nilai Etis dalam Wayang dan Pendidikan Watak Guru. Disertasi tidak diterbitkan. Malang: Program Pascasarjana IKIP.

Atmosuwito, S. (2010). Perihal Sastra Religiusitas dalamSastra. Bandung:SinarBaruAlgensindo.

Dayakisni, T.\& Yuniardi S. (2004). Psikologi Lintas Budaya. Malang: UMM.

Djamaluddin, H. (2004). Indonesia, Masihkah Engkau Tanah Airku? Jakarta: Pustaka Jaya.

Ganap, Victor. (2012). Konsep Multikultural dan Etnisitas Pribumi dalam Penelitian Seni. Humaniora, 24 (2).

Gazalba, S. (1998). Sistematika Filsafat III. Jakarta: Bulan Bintang.

Iskandar, T. (1998). Kamus Dewan. Kuala Lumpur: Dewan Bahasa dan Pustaka.

Kristiatmo, T. (2007). Redefinisi Subjek dalam Kebudayaan. Yogyakarta: Jalasutra.

Liliweri, A. (2003).Makna Budaya dalam Komunikasi Antarbudaya. Yogyakarta: LKiS.

Mahfud, C. (2006). Pendidikan Multikultural. Yogyakarta: Pustaka Pelajar.

Maryaeni. (2013). Pendidikan Karakter dan Multikultural: Pilar Kebangsaan dan Pendidikan". ATIKAN: Jurnal Kajian Pendidikan, 3(2).

Mulyana, R. (2004). Mengartikulasikan Pendidikan Nilai. Bandung: Alfabeta.

Oentoro, Jimmy B. (2011). The 7-40, 7 Prinsip yang akan Mengubah Kehidupan Anda dalam 40 Hari. Jakarta: Gramedia Pustaka Utama.

Rafiek, M. 2010. Teori Sastra: Kajian Teori dan Praktik. Bandung: Refika Aditama.

Rasuanto, B. (2005). Kejadian Sosial: Pandangan Deontologis Rawls dan Habermas Dua Teori Filsafat Politik Modern.

Ricouer, P. (1981). Hermeneutika Ilmu Sosial. Terjemahan Muhammad Syukri. 2006. Yogyakarta: Kreasi Wacana. 
Ricouer, P. (2003). Filsafat Wacana. Terjemahan Masnur Hery. Yogyakarta: IRCiSod.

Suparlan, P. (2004). Hak-hak Minoritas dalam Landscape Multikultural, Mungkinkah di Indonesia. Makalah disajikan dalam Workshop Yayasan Interseksi, Wisma PKBI, 10 Agustus 2004, (Online), (http://www. interseksi.org/ publications/essays/articles/ masyarakat majemu.html), diakses 16 Februari 2009.
Suratno (2005). Pluralisme Agama dalam Hermeneutika Paul Ricoeur. Jurnal Universitas Paramadina, 4(1): $105-110$.

Yunus, et al. (2004). Husni Djamaluddin Yang Saya Kenal.Jakarta: Pustaka Jaya. 